\title{
ПРОБЛЕМЫ АДМИНИСТРАТИВНО-ПРАВОВОГО РЕГУЛИРОВАНИЯ ДЕЯТЕЛЬНОСТИ АКЦИОНЕРНЫХ ОБЩЕСТВ
}

\begin{abstract}
Аннотация: совершенствование административного законодательства, регламентирующего деятельность акционерных обществ, должно осуществлять на основе учета норм, действующих в государствах Европейского союза, а вступление Российской Федерации во Всемирную торговую организацию и Европейский экономический союз диктует необходимость развития и укрепления административно-правового статуса акционерных обществ. Следует также подчеркнуть, что в настоящее время имеет место потребность в более четком определении такой категории, как коллективный субъект административного права, а также разработке системы эффрективных административно-правовых средств воздействия на деятельность непосредственно акционерных обществ. Методологическую основу статьи составили современные достижения теории познания. В процессе исследования применялись общефилософский, теоретический, общефилософские методы (диалектика, системный метод, анализ, синтез, аналогия, дедукция, наблюдение, моделирование), традиционно правовые методы (формально-логический), а также методы, используемые в конкретно-социологических исследованиях (статистические, экспертные оченки и др.). Как отмечается в научной литературе: «на современном этапе социально-экономического развития Российской Федерации все большую актуальность приобретают проблемы, касающиеся создания эффективных административно-правовых механизмов регулирования деятельности акционерных обществ. Гражданскоправовая регламентация деятельности акционерных обществ не исчерпывает всего разнообразия форм и методов правового регулирования, особенно когда речь идет о крупных корпорациях с государственным участием». Исследование особенностей механизма административно-правового регулирования деятельности акционерных обществ имеет большое значение, как в теоретическом, так и практическом плане, поскольку позволяет выявить проблемы в реализации правовых норм и выработать пути совершенствования действующего законодательства.
\end{abstract}

Ключевые слова: регулирование, общество, акционер, акция, механизм, воздействие, администрирвоание, контроль, служба, государство.

$\mathrm{B}$ настоящее время государство посредством органов государственной власти регулирует определенные сферы общественных процессов и отношений, устанавливая правила и порядок поведения и деятельности субъектов этих отношений. Для этого оно использует весь находящийся в его распоряжении арсенал возможностей юридического воздействия. Такое воздействие, имея правовой характер и выражение, осуществляется при помощи механизма правового регулирования. Он приводится в действие в результате примене- ния взаимоувязанных и согласованно функционирующих элементов, условно образующих в своей совокупности сам этот механизм. Как отмечается в научной литературе: «на современном этапе социально-экономического развития Российской Федерации все большую актуальность приобретают проблемы, касающиеся создания эффективных административно-правовых механизмов регулирования деятельности акционерных обществ. Гражданско-правовая регламентация деятельности акционерных обществ не исчерпывает всего раз- 
нообразия форм и методов правового регулирования, особенно когда речь идет о крупных корпорациях с государственным участием» ${ }^{1}$.

Исследование особенностей механизма административно-правового регулирования деятельности акционерных обществ имеет большое значение, как в теоретическом, так и практическом плане, поскольку позволяет выявить проблемы в реализации правовых норм и выработать пути совершенствования действующего законодательства.

Под механизмом понимается «система, устройство, определяющее порядок какого-нибудь действия ${ }^{2}$. С.А. Комаров ${ }^{3}$ пишет, что в настоящее время понятие «механизм» употребляется в юридической науке под разными углами зрения. Например, Ю.И. Гревцов ${ }^{4}$ отмечает механизм осуществления права, В.П. Казимирчук ${ }^{5}$ описывает механизм действия права. Целесообразно будет привести понятия и других механизмов. Так под государственным механизмом понимается «совокупность всех структур государства, осуществляющих систематическое и непрерывное управляющее воздействие на общество, поведение и деятельность людей» 6 .

В экономическом словаре мы можем видеть, что механизм определяется, как внутреннее устройство чего-либо, приводящее его в действие, как систему, определяющую порядок какого-либо вида деятельности ${ }^{7}$. Механизм действия Конституции «комплекс мер (средств) юридического, организационного, материально-финансового и иного характера, направленных на создание условий фактического достижения целей Основного закона» ${ }^{8}$. Из всех выше приведенных определений видно, что «механизм»

1 См.: Петухов В. Некоторые вопросы административноправового регулирования организации и деятельности корпораций в России // Право и экономика. - 2000. - № 4.

2 См.: Ожегов С.И. Толковый словарь русского языка. - М., 2002. - C. 354.

3 См.: Комаров С.А. Механизм правового воздействия. Общая теория государства и права / Отв. ред. М.Н. Марченко. M., 1998. - C. 438.

4 См.: Гревцов Ю.И. Правовые отношения и осуществление права. - Л., 1987.

5 См.: Казимирчук В.П.Современная социология права. M., 1995. - С. 73.

6 См.: Иванец Г.И. Конституционное право России: энциклопедический словарь. - М., 2002. - С. 239.

7 См.: Краткий экономический словарь / Под ред. А.Н. Азриеляна. - М., 2001. - С. 401.

8 См.: Иванец Г.И. Указ. соч. - С. 239.
- это всегда некая организованная совокупность частей, подчиненная единой задаче.

Для уяснения сущности механизма административно-правового регулирования деятельности акционерных обществ, необходимо определить само понятие механизм правового регулирования.

Важно отметить, что в юридической литературе нет единого мнения относительно понятия механизма правового регулирования. Впервые в термин механизм правового регулирования ввел и раскрыл его содержание С.С. Алексеев. «Механизм правового регулирования может быть определен, как взятая в единстве система правовых средств, при помощи которой, обеспечивается результативное правовое воздействие на общественные отношения» ${ }^{9}$.

В данном определении автор акцентирует внимание на том, что право оказывает регулирующее воздействие с помощью набора разнообразных юридических средств, так как невозможно оказывать упорядочивающее воздействие на общественные отношения, лишь за счет одного элемента механизма правового регулирования. И лишь такая совокупность приводит различные юридические средства в единую систему - механизм правового регулирования.

В качестве критерия выделяющего основные элементы механизма правового регулирования, С.С. Алексеев предложил использовать стадии правового регулирования ${ }^{10}$. К их числу относятся:

- стадия формирования и действия юридических норм;

- стадия возникновения прав и обязанностей (правоотношений);

- $\quad$ стадия реализации прав и обязанностей;

- $\quad$ стадия применения права.

Примерно так же, характеризуют процесс правового регулирования и многие ученые, отличие заключается лишь в названии первой стадии. Например, А.В. Мальков пишет о стадии издания норм права и ее общего воздействия ${ }^{11}$. А.Ф. Черданцев, в качестве первой стадии, называет стадию общенормативного регулирования и исключает четвертую стадию -применение права ${ }^{12}$.

\footnotetext{
9 См.: Алексеев С. С. Теория права. - М., 1994. - С. 220.

10 См.: Алексеев С.С. Общая теория права. - М., 1982. - С. 26.

11 См.: Общая теория государства и права / Под ред. М.Н. Марченко. - М., 1998. - С.439.

12 См.: Черданцев А.Ф. Теория государства и права. - Екатеринбург, 1996. - С. 166.
} 
С.С. Алексеев отмечает, что под строго инструментальным углом зрения в механизме правового регулирования, в соответствии с его стадиями, выделяются три основных звена: юридические нормы - основа правового регулирования; правовые отношения, субъективные права и юридические обязанности, переводящие правовую энергию юридических норм, на уровень конкретных субъектов - носителей прав и обязанностей; акты реализации прав и обязанностей.

В ряде случаев, в механизм правового регулирования включается и четвертое звено - акты применения права, а также некоторые дополнительные элементы - индивидуальные акты, правоположения практики и др.

Здесь важно отметить, что концепция, созданная С.С. Алексеевым, признается многими учеными-правоведами, но не является единственной. Исследованию механизма правового регулирования посвятили свои работы: А.С. Пиголкин ${ }^{13}$, В.Н. Хропанюк ${ }^{14}$, Л.И. Спиридонов ${ }^{15}$, Т.Н. Радько ${ }^{16}$, А.В. Петров $^{17}$, А.В. Малько ${ }^{18}$ и др. Из анализа определений механизма правового регулирования перечисленных авторов, можно сделать вывод о том, что многие ученые придерживаются предложенного С.С. Алексеевым понятия. У некоторых авторов прослеживается лишь небольшое расширение данного понятия.

Таким образом, механизм правового регулирования можно определить, как «нормативно-организованная совокупность правовых средств, оказывающая властное воздействие на общественные отношения, осуществляемая в соответствии с целями и задачами правового государства».

Понятие механизма правового регулирования позволяет, не только собрать вместе явления правовой действительности (нормы, правоотношения, юридические акты и др.), участвующие в правовом воздействии, и обрисовать их, как це-

13 См.: Теория государства и права / Под. ред. А.С. Пиголкина. - М., 2006. - С.457.

14 См.: Хропанюк В.Н. Теория государства и права. - М., 1995. - C. 341.

15 См.: Спиридонов Л.И. Социальный механизм уголовноправовых запретов. - М., 1976. - С.5.

16 См.: Радько Т.Н. Теория государства и права. - М., 2001. C. 319 .

17 См.: Петров А.В. Теория государства и права. - Нижний Новгород, 1997. - С. 73.

18 См.: Теория государства и права / Под. ред. Матузова Н.И., Малько А.В. - М., 2001. - С. 726. лостность (это достигается и при помощи понятия «правовая система»), но и представить их в работающем, системно-воздействующем виде, что характеризует результативность правового регулирования; высветить в связи с этим специфические функции, которые выполняют те или иные юридические явления в правовой системе; показать их связь между собой и взаимодействие ${ }^{19}$.

По нашему мнению, некоторые авторы слишком расширительно толкуют содержание механизма правового регулирования, включая правопорядок и законность, правосознание и правовую культуру, деятельность госорганов и должностных лиц, направленную на претворение в жизнь правовых норм. При определении содержания механизма правового регулирования и его составных частей, ряд авторов исходит из соотношения отдельных правовых явлений, и первичности одного правового явления, по отношению к другому. На наш взгляд, исходить необходимо из того, оказывают ли регулирующее воздействие на общественные отношения те или иные правовые явления, в какой бы зависимости они между собой не находились, так как целью правового регулирования является упорядочение общественных отношений. Ведь вопрос связи и соотношения отдельных элементов механизма правового регулирования, это, в первую очередь, вопрос его структуры.

Механизм административно-правового регулирования, являясь частью системы механизма правового регулирования в целом, содержит, по существу, тот же набор правовых средств (правовые нормы, правоотношения, акты применения права), с помощью которых осуществляется упорядочивающее воздействие на общественные явления. Однако, механизму административно-правового регулирования присущи свои специфические особенности. Эти особенности можно рассматривать: в вертикальном разрезе, где составляющие его правовые средства, расположены в соответствующем их назначению иерархическом порядке - административно-правовые нормы, административноправовые отношения, административно-правовые акты; в горизонтальном разрезе. В данном случае механизм правового регулирования представляется в виде единого образования, состоящего из отдельных, самостоятельных и практически равноправных блоков, являющихся отраслевыми механизмами правового регулирования. При этом, каждый отраслевой блок, несмотря на специфиче-

19 См.: Алексеев С.С. Общая теория права. - М., 1982. - С. 26. 
ское юридическое своеобразие, тем не менее, представляет собой составную часть общего механизма правового регулирования, отражающую его особенности через предмет, метод, систему ${ }^{20}$.

Ю.А. Дмитриев, И.А. Полянский, Е.В. Трофимов определяют механизм административно-правового регулирования, как «упорядоченную по стадиям регулирования систему административно-правовых средств воздействия на общественные отношения в сфере организации и осуществления государственного управления» ${ }^{21}$.

По мнению Ю.Н. Старилова, вместо термина «механизм административно-правового регулирования», целесообразнее говорить о системе административно-правового регулирования. Система административно-правового регулирования позволяет в комплексе увидеть материю административного права; она дает возможность понять логику административно-правового воздействия на общественные отношения, выделить главные элементы организационно-правового воздействия и регулирования этих отношений. ${ }^{22}$

Ю.Н. Старилов в систему административноправового регулирования включает следующие элементы:

1. Административно-правовые нормы, как первичные элементы административного регулирующего воздействия на общественные отношения. Нормы административного права содержатся в федеральных законах, законах субъектов РФ, указах Президента РФ, и многих других актах. Д.Н. Бахрах особо отмечает, что в системе административного правового регулирования, правовым нормам отводится центральное место, ибо их отсутствие, непременно приведет к безжизненности всей системы функционирования административного права.

2. Применение норм административного права субъектами права. От качественности и правильности правоприменения зависит конечный результат административно-правового воздействия. В процессе применения норм

20 См.: Веремеенко И.И. Механизм административно-правового регулирования в сфере охраны общественного порядка. - М., 1981. - С. 48.

21 См.: Дмитриев Ю.А., Полянский И.А., Трофимов Е.В. Административное право Российской Федерации. - М., 2008. C. 21.

22 См.: Бахрах Д. Н., Российский Б.В, Старилов Ю. Н. Административное право. - М., 2005. - С. 98. административного права возникают сложности, неясности, коллизии, следовательно, необходимость их толкования в случае разногласий между субъектами правоприменения, сомнения в правильности действий, или в конституционности самой административноправовой нормы.

3. Административно-правовые отношения, которые создаются в результате действия и применения норм административного права. Правоотношения завершают формирование этой системы, а установление законных управленческих (административных) отношений и являются, по сути, главной целью процесса административно-правового регулирования. Этому служат, как созданные правовые нормы, так и их применение на практике, применительно к конкретным отношениям. Административно-правовые отношения содержат в себе соответствующие права, обязанности, ответственность участников правоотношений.

B.C. Четвериков считает, что система элементов механизма административно-правового регулирования состоит из:

1. норм административного права, регулирующих принципы организации и деятельности органов исполнительной власти, государственного управления; формирования целей, постановки задач; определение функций, компетенций органов исполнительной власти, государственного управления;

2. актов толкования норм административного права, а также актов, разъясняющих практику применения вышестоящих актов управления;

3. индивидуальных актов;

4. актов применения норм административного права;

5. административно-правовых отношений в сфере деятельности органов исполнительной власти, государственного управления - это, прежде всего, урегулированные нормами административного права полномочия, функции, задачи, права, обязанности и ответственность субъектов этих отношений ${ }^{23}$.

По мнению В.С. Четверикова, особое значение в системе элементов механизма административноправового регулирования, занимает правосознание граждан, методы убеждения и административного принуждения. Правосознание представляет

23 См.: Четвериков В.С. Административное право. - М., 2010. - C. 75. 
совокупность идей, взглядов, мнений, выражающих определенные отношения людей, их социальных групп к нормам права, правоприменительной деятельности, правосудию. Метод убеждения, является основным методом добровольного и добросовестного исполнения гражданами своих обязанностей в сфере управленческих отношений, без каких-либо угрожающих санкций за невыполнение норм, и правил поведения, регламентированных административно-правовыми нормами.

Из проведенного анализа существующих понятий «механизма административно-правового регулирования» можно сделать вывод, что в юридической литературе сформировалось единое представление о содержании данного понятия, предполагающее, что система административноправовых средств, в той или иной мере связанных с административно-правовой нормой, образует нормативную основу механизма административно-правового регулирования. Административно-правовые средства, относящие к строго определенному элементу механизма, вступают в процесс регулирования с конкретной последовательностью, направленностью, и на конкретной стадии. Границы административно-правового регулирования строго ограничены, с одной стороны вступлением в силу правовых норм, а с другой, реализацией обязанностей и прав участников правоотношений.

С учетом исследованных нами особенностей административно-правового регулирования, на наш взгляд, возможно выделение трех основных элементов механизма административно-правового регулирования деятельности акционерных обществ.

А. Нормы административного права, регулирующие деятельность акционерных обществ. Задача административно-правовых норм, направленных на регулирование деятельности акционерных обществ, сводится к определению правил поведения, которым должны следовать субъекты в процессе государственного властного регулирования. Выполняя данную функцию нормы права, определяют круг субъектов, их правовое положение, основания возникновения, изменения и прекращения правовых связей и т.д.

В. Государственные органы, осуществляющие контроль над акционерными обществами. Данные госорганы представляют собой целостную систему, объединенную едиными целями и задачами по осуществлению кон- трольно-надзорной, разрешительной, координационной, нормотворческой, информационной функциями административно-правового регулирования деятельности АО.

C. Юридические процедуры - представляют собой элемент механизма административно-правового регулирования деятельности акционерных обществ, поскольку в них заложена активная поведенческая характеристика реализации норм права через правомерное поведение субъектов. В ходе реализации рассматриваемого нами механизма, не возможно осуществить предписания установленные нормой права без указания на действия, которые необходимо осуществить в процессе правореализации.

Каждый из данных основных элементов выполняет в процессе административно-правового регулирования свои, специфические функции. В этой связи представляется целесообразным проанализировать названные элементы механизма с целью определения их особенностей

Из анализа механизма правового регулирования и механизма административно-правового регулирования видно, что они частично совпадают, но в случае, если речь идет о государственном управлении деятельности акционерными обществами, то особую роль играют субъекты регулирования, осуществляющие властное воздействие.

В данном случае государство, как субъект правового регулирования развивает административное, гражданское, корпоративное законодательство, нормы которого направлены на регулирование деятельности акционерных обществ, с другой стороны выполняет регистрационные, регулирующие, лицензирующие, контрольные функции и одновременно с этим выступает в качестве субъекта гражданского права.

Причем законодательная, регулирующая и предпринимательская деятельности государства достаточно четко выражены, особенно в случаях участия государства в крупных акционерных обществах. Государство, выполняя свои функции, становится учредителем акционерных обществ, входит в состав, включает своих представителей в органы управления акционерными обществами, оказывает господдержку промышленно важным акционерным обществам.

С одной стороны государство осуществляет воздействие на акционерные общества как субъект публичного права посредством взимания налогов, нормативно-правового регулирования, лицензи- 
рования и т.д. А с другой стороны, государство осуществляет воздействие на акционерные общества как субъект частного права. При этом правовое регулирование осуществляется не только со стороны гражданского, но и административного права, поскольку деятельность акционерных обществ связана как с реализацией частных, так и публичных интересов. И в этой связи особую значимость приобретает административно-правовое регулирование как один из основных видов государственного воздействия в этой сфере. При этом государственным органам как субъектам административно правового регулирования отводится наиболее важная и объемная роль - непосредственное и повседневное осуществление государственно-властного воздействия на общественные отношения, связанные с деятельность акционерных обществ, а также защита прав и охраняемых законом интересов прав акционеров.

С учетом рассмотренного материала представляется возможным дать определение «механизма административно-правового регулирования деятельности акционерных обществ».

Механизм административно-правового регулирования деятельности акционерных обществ, представляет собой упорядоченную совокупность взаимосвязанных и взаимодействующих административно-правовых средств, при помощи которых, обеспечивается результативное правовое воздействие на общественные отношения, представляющих повторяющуюся совокупность последовательно осуществляемых операций, или стадий, в соответствии с целями, задачами и функциями регулирования деятельности акционерных обществ.

Также подчеркнем, что механизм административно-правового регулирования деятельности акционерных обществ имеет достаточно сложную структуру и обладает особой спецификой. Каждый из его элементов играет особую роль в механизме осуществления государственно-властного контроля над деятельностью акционерных обществ. Рассматриваемый нами механизм обладает особыми источниками, задачами и функциями правового регулирования; отличительным нормотворческим и правоприменительным статусом государственных властных органов, осуществляющих контроль; особым правовым статусом субъектов и, что самое важное, специальными областями возникновения общественных отношений. Отдельно хотелось бы отметить, что в настоящее время необходимо совершенствовать каждый из элементов механизма государственно-правового регулирования деятельности акционерных обществ. В особой степени в совершенствовании нуждаются нормы права, определяющие режим осуществления контрольно-надзорной деятельности над акционерными обществами.

Во исполнение Указа Президента РФ от 18 июля 2008 г. «0 совершенствовании Гражданского кодекса Российской Федерации» ${ }^{24}$ Советом при Президенте РФ по кодификации и совершенствованию гражданского законодательства и Исследовательским центром частного права при Президенте РФ разработана «Концепция развития гражданского законодательства» ${ }^{25}$ (далее - Концепция), которая, по нашему мнению, станет движущей силой для совершенствования элементов механизма административно-правового регулирования деятельности акционерных обществ.

В общей части ГК РФ предлагаемые в Концепции изменения коснутся статуса юридических лиц. Предусматривается ужесточение требований к порядку создания, регистрации, реорганизации и ликвидации, а также к уставному капиталу юридических лиц. Предлагается ввести юридическую экспертизу достоверности учредительных документов, представляемых в регистрирующий орган, а саму регистрацию передать в органы юстиции.

Из анализа положений Концепции, можно определить следующие направления развития гражданского законодательства об акционерных обществах: отказ от деления акционерных обществ на открытые и закрытые; сокращение и детализация законодательных актов, направленных на регулирование акционерных обществ; видоизменение акционерных отношений в сторону гибкости и публичности; усиление роли общих положений Гражданского кодекса; увеличение имущественной ответственности исполнительных органов; создание ограничений в отношении размера уставного капитала; включение в Гражданский кодекс большего числа императивных норм.

Не ставя целью, исчерпывающее рассмотрение всех изменений, предложенных в Концепции, сосредоточимся на положениях в наибольшей степени затрагивающих механизм и сам порядок административно-правового регулирование деятельности акционерных обществ.

Многие критики Концепции и Гражданского кодекса отмечают, что ГК РФ консолидирует в себе все больше административно-правовых норм в от-

24 См.: Собрание законодательство РФ. - 2008. - №29 (ч.1). Ст. 3482.

25 См.: Вестник ВАС РФ. - 2009. - № 11. 
ношении юридических лиц и, следовательно, утрачивает качества частноправового закона ${ }^{26}$.

Это можно объяснить тем, что отрасль законодательства включает в себя законы и иные нормативные акты, которые в свою очередь в силу жизненных реалий не содержат нормы исключительно какой-либо одной отрасли права (в качестве примера можно назвать транспортные кодексы, которые содержат в себе нормы административного права). Наличие административно-правовых норм в Гражданском кодексе является неизбежным явлением и многие положения ГК, содержащие нормы административного характера, бессмысленны вне и без гражданского законодательства.

Также следует отметить, что на основании ст. 72 Конституции РФ административное законодательство является предметом совместного ведения Российской Федерации и ее субъектов, тогда как Гражданское законодательство в силу ст. 71 Конституции РФ отнесено к исключительному ведению Российской Федерации. И в случае изъятия из Гражданского кодекса норм, которые по замыслу являются административно-правовыми, неизбежно придется дополнительно принимать ряд отдельных Федеральных законов. В то время как в п. 1.1. Гл. 3 Концепции разработчики указывают, что «нецелесообразно создание и функционирование отдельных законов общего характера, составляющих дополнительный уровень регулирования «между» ГК и законами об отдельных видах юридических лиц. Гражданско-правовая регламентация и в этой сфере должна остаться «двухуровневой».

По замыслу разработчиков Концепции, планируемые изменения Гражданского кодекса будут способствовать дальнейшему сближению основополагающих норм российского права с подходами классических европейских континентальных кодификаций. Речь идет о том, чтобы сохранить все то, что выдержало проверку временем, учесть накопленный опыт, с учетом развития гражданского права в странах Европы (Германии, Франции, Нидерландов) с тем, чтобы наше законодательство не отставало от законодательства США и ЕС, так как современная мировая экономика представляет собой единый глобализированный механизм. Учитывая это, несколько слов скажем об акционерном законодательстве Франции. В этой стране в середине 60-х годов XX в. была осуществлена крупная

26 См.: Толстой Ю.К. О Концепции развития гражданского законодательства // Журнал российского права. - 2010. № 1. - С. 32. реформа акционерного законодательства, в связи с которым акционерное общество признавалось одной из разновидностью торговых товариществ. По законодательству Франции того периода акционерная компания приобретает право юридического лица с момента регистрации ее в торговом реестре $^{27}$.

Важно отметить тот факт, что в Концепции сочетаются конструкции континентального и англо-саксонского права. Ведь законодательство об акционерных обществах и элементы механизма административно-правового регулирования деятельности акционерных обществ находятся в постоянном движении. При этом, как нами уже отмечалось ранее, происходит постоянное сближение многих правовых конструкций. Страны Европейского Союза постоянно заимствуют что-то из американского права, а США в свою очередь перенимает опыт французского и немецкого законодательства об акционерных обществах. Российская Федерация является неотъемлемой частью мировой экономики, и следование передовому опыту зарубежных стран является вполне оправданным и жизненно необходимым явлением.

Глобализация законодательства является бесспорным фактом, и встраивание России в мировую экономику жизненно важно для развития полноценной экономики государства. Соответственно изменение внутреннего законодательства России и сближение его с законодательством ЕС и США является необходимой задачей, способной повысить качество принимаемых законов в целом. Но важно учитывать, что способность закона наиболее эффективно регулировать общественные отношения зависит от целого ряда факторов, как внутренних, вытекающих из самого закона, так и внешних, т.е. условий, в которых он будет реализовываться. Наиболее важным фактором является качество и глубокий уровень проработанности концепции закона, так как при подготовке ошибочной концепции закона законодатель может не только не достигнуть желаемого результата, но и вызвать негативные последствия.

Так одним из самых важных новшеств Концепции и одновременно самой главной ошибкой законодателя, по нашему мнению, является предложение установить минимальный уставной капитал для акционерных обществ в размере 2 миллионов рублей. Главным аргументом в пользу увеличения уставного

27 См.: Кулагин М.И. Акционерное законодательство Франции: Автореф. дис. ... канд. юрид. наук. - М., 1974. - С. 4. 
капитала называется обеспечение защиты прав кредиторов в случае банкротства общества.

Мы провели анализ судебной практики по данному вопросу за последние 10 лет. Но, к сожалению, в судебной практике нет ни одного дела, где кредиторы обращали бы взыскание на уставный капитал должника-организации при ведении процедуры банкротства ${ }^{28}$. В данном случае причиной отсутствия подобного рода судебной практики можно назвать неверие кредиторов в уставный капитал общества. Чаще всего оплата уставного капитала это просто формальность, сразу после регистрации компании внесенные деньги или имущество уйдут на сторону, по существу, обратно тому, кто их и внес.

Также нами был проведен анализ судебной практики банкротства крупных акционерных обществ (банков, кредитных организаций, участников рынка ценных бумаг и т.п.) ${ }^{29}$. Следует отметить, что мы анализировали дела по банкротству публичных акционерных обществ, имеющих большой уставной капитал, оплаченный различного рода имуществом частных лиц. Данные организации находились под пристальным вниманием ФСФР, прошли аудит и сдали отчетность об уровне достаточности капитала, величине резервов на покрытие сомнительных ссуд и иных активов. Но, как и в случаях с небольшими организациями, при процедуре банкротства ни какая достаточность собственного капитала и большой размер уставного капитала не защищает интересов кредиторов.

Например, в ЕС несколько лет назад рассматривался вопрос об отказе от уставного капитала, но после длительного обсуждения от этой идеи было решено отказаться, и в ряде стран были приняты законы, позволяющие создавать фирмы с уставным капиталом в размере 1 евро, с последующей оплатой в полном объеме. Однако в ЕС даже не рассматривается вопрос о повышении уставного капитала. Ведь высокий уровень уставного капитала может стать серьезным препятствием для создания малого бизнеса и в значительной степени затормозить развитие экономики и создание новых рабочих мест.

28 См.: Постановление ФАС Волго-Вятского округа от 29 мая 2008 г. по делу № А11-8337/2007-К1-140Б/7Б, Определение ВАС РФ от 18 мая 2010 г. № ВАС-6125/10 по делу № A51-14241/2008-15-115/356.

29 См.: Решение Арбитражного суда г. Москвы от 24 мая 2011 г. по делу № А40-22551/11-4-110Б, Решение Арбитражного суда г. Москвы от 7 декабря 2010 г. по делу № А40$119763 / 10-73-565$.
К сожалению, российские законодатели, решая важные задачи посредством действенных, по их мнению, юридических решений, зачастую могут нанести непоправимый ущерб экономике государства. Повышая уставный капитал - законодатель повышает входной барьер для ведения бизнеса. Понятно, что от такого решения страдают не только недобросовестные предприниматели, но и, в первую очередь, законопослушные граждане, намеревающиеся создать бизнес. Подобного рода входной барьер становится для них непреодолимым препятствием.

Как обозначил в своей речи на бизнес-саммите «Группы двадцати» в Сеуле Д.А. Медведев «Очевидно, что именно малый бизнес, который позволяет начать собственное дело, может смягчить последствия кризиса, обеспечить дополнительную занятость и рост производства. То есть обеспечить потребительский спрос на рынке и сыграть главную роль в стимулировании экономического роста - того, что нам сейчас так не хватает в масштабах глобальной экономики и экономики отдельных стран.

Поэтому нам нужно пытаться не просто восстановить прежние условия функционирования малых и средних предприятий, но и сформировать для них более благоприятную среду.

Правительства в этом плане должны больше внимания уделять вопросам улучшения предпринимательского климата, оптимизации условий ведения бизнеса, снижения административных барьеров, предоставлять преференции, которые будут осваиваться малыми и средними компаниями для создания передовых технологий». ${ }^{30}$

Вряд ли под улучшением предпринимательского климата и снижением административных барьеров, наш Президент подразумевал увеличение размера минимального уставного капитала ОАО в 20 раз. И явно, что подобного рода действия законодателя не повлияют в положительную сторону на оптимизацию условий ведения бизнеса в России, в том числе деятельность акционерных обществ.

По нашему мнению, если государство намеренно защищать права кредиторов то, более целесообразно было бы сосредоточиться законодателю на проработке и более тщательном анализе законодательства о банкротстве ${ }^{31}$, раскрытии информации

30 См.: Речь Президента Д.А. Медведева на бизнес-саммите «Группы двадцати» в Сеуле. [Электронный ресурс]. - Режим доступа: URL: www.президент.pф/новости/9480

31 В данном случае имеется в виду банкротство акционерных обществ, банкротство ООО не рассматривается. 
акционерными обществами и правовом регулировании деятельности субъектов административного контроля, осуществляющих надзор за акционерными обществами.

В рамках рассмотрения механизма административно-правового регулирования деятельности акционерных обществ наиболее важным является общий анализ государственных органов, задействованных в управлении акционерными обществами которые не участвуют в регулировании других коммерческих организаций и контроле за отдельными видами деятельности. (Подробному же анализу субъектов административно-правого регулирования осуществляющих контроль за деятельностью акционерных обществ, будет посвящен отдельный параграф.)

Указом предусмотрено, что Министерство финансов Российской Федерации осуществляет функции по выработке и реализации государственной политики и нормативно-правовому регулированию в сфере финансовых рынков. В данном случае мы видим, что законодатели пошли по пути разделения надзора и нормативно-правового регулирования.

Таким образом, сложилась раздробленность регулирования, в результате которой отсутствует единая система мониторинга, охватывающая все сегменты деятельности акционерных обществ и функционирования финансового рынка.

С учетом вышеизложенного, на наш взгляд, в целях дальнейшего развития законодательства об акционерных обществах, а также оптимизации процессов принятия решений по вопросам стратегического развития финансового рынка, было бы целесообразно дополнить п. 5 «Положения о Федеральной службе по финансовым рынкам» подпунктом 5.15, изложив его в следующей редакции:

5.15 Разрабатывает основные направления развития рынка ценных бумаг и координации деятельности федеральных органов исполнительной власти по вопросам регулирования рынка ценных бумаг.

Единство всех элементов механизма административно-правового регулирования деятельности акционерных обществ достигается путем выделения среди государственных органах как особого регулятора, осуществляющего контроль над акционерными обществами. Последние результаты административной и корпоративной реформ ясно показывают, что значение административноправового регулирования в рассматриваемой сфере будет только возрастать. Однако осуществлять контроль за деятельностью акционерных обществ невозможно только путем совершенствования структуры и полномочий государственных органов, являющихся одним из элементов механизма административно-правового регулирования. Эти органы выполняют регулятивную функцию в совокупности со всеми другими средствами юридического воздействия. Именно поэтому необходимо говорить о механизме административно-правового регулирования, как о совокупности юридических средств.

Наличие юридических процедур является характерной особенностью рассматриваемого нами механизма и имеет для него особое значение.

Для механизма административно-правового регулирования деятельности акционерных обществ юридические процедуры имеют сквозное значение, так как они обеспечивают действие трех блоков названного механизма - регулятивного, oxранительного, правотворческого.

Юридические процедуры представляют собой систему, которая:

a) ориентирована на достижение конкретного правового результата;

б) состоит из последовательно сменяющих друг друга актов поведения и как деятельность внутренне структурирована правовыми отношениями;

в) обладает моделью (программой) своего развития, предварительно установленной на нормативном или индивидуальном уровне;

г) иерархически построена;

д) постоянно находится в динамике, развитии;

е) имеет служебный характер: выступает средством реализации основного, главного для нее правового отношения ${ }^{32}$.

За последнее время в законодательство были внесены существенные изменения, затрагивающие юридические процедуры механизма административно-правового регулирования деятельности акционерных обществ. «В значительной степени эти изменения коснулись порядка информационного сопровождения деятельности эмитентов ценных бумаг - раскрытия информации» ${ }^{33}$. Так, к примеру, в подготовленной Концепции развития гражданского законодательства раскрытию информации акционерными обществами отводится

32 См.: Протасов В.Н.Теория государства и права. - М., 2009. - C. 124.

33 См.: Агенорова-Папуловская А. АО стремятся к раскрытию // ЭЖ-Юрист. - 2011. № 17. - С.15. 
одно из центральных мест. Эта идея, на наш взгляд, заслуживает поддержки, поскольку ее реализация будет в большей степени способствовать обеспечению прав акционеров.

Полное раскрытие информации жизненно важно для оживления внутреннего инвестиционного климата. Оно будет способствовать решению следующих задач:

- предоставлению инвесторам и кредиторам информации, необходимой для принятия взвешенного решения;

- защите кредиторов от мошенничества, поскольку создаст препятствия случаям использования конфиденциальной информации инсайдерами и разрешит проблему конфликта интересов, обеспечивая контроль над действиями руководства общества;

- позволит осуществлять контроль за деятельностью акционерных обществ со стороны государственных органов.

Статья 92 ФЗ «Об акционерных обществах», предусматривает обязанность ОАО раскрывать:

- годовой отчет общества, годовую бухгалтерскую отчетность;

- $\quad$ сообщение о проведении общего собрания акционеров;

- проспект эмиссии акций общества в случаях, предусмотренных правовыми актами РФ;

- иные сведения, определяемые органами исполнительной власти по рынку ценных бумаг. Нами был проведен анализ практики привлечения акционерных обществ к ответственности за нарушение порядка раскрытия информации эмитентами ценных бумаг. Он показал, что наиболее частыми являются следующие нарушения по публичному раскрытию информации:

1. Самым распространенным нарушением по раскрытию информации является непредставление ежеквартальных отчетов и несоблюдение иных требований по раскрытию информации вследствие неправильного отнесения компании к обществам, не обязанным раскрывать такую информацию. Такие нарушения являются самыми распространенными ${ }^{34}$.

2. Неполное раскрытие информации. Часто такое нарушение связано с некачественной подготовкой ежеквартального отчета эмитента

34 См.: Постановление ФАС Уральского округа от 25 января 2010 г. № Ф09-11267/09-С1, Постановление ФАС Московского округа от 7 декабря 2009 г. № КА-А40/12863-09 по делу № A40-65550/09-147-664. эмиссионных ценных бумаг и иных документов, подлежащих раскрытию; с неправильной интерпретацией требований законодательства; сознательным уклонением от раскрытия информации ${ }^{35}$.

3. Отказ акционерного общества в получении акционерами запрашиваемой информации ${ }^{36}$.

4. Неправильное оформление документов ${ }^{37}$.

5. Нераскрытие отдельных фактов, нарушение сроков раскрытия информации. Данное нарушение достаточно часто встречается в судебной практике. Чаще всего в своей деятельности акционерные общества задерживают подготовку документов для раскрытия соответствующей информации до последнего момента из-за появляющихся нюансов и тем самым допускают просрочку на несколько дней ${ }^{38}$.

6. Нарушение требований по раскрытию информации на сайте общества. Так же часто отмечаются случаи раскрытия в Интернете текста годовой бухгалтерской отчетности не в полном объеме, часто забывают раскрыть аудиторское заключение и пояснительную записку ${ }^{39}$.

7. Противоречивость информации в различных документах. Расхождение в отчетной информации обусловлено недостаточно серьезным отношением к обязанности по ее раскрытию. Потенциальный кредитор, инвестор, а также акционеры в этом случае дезориентированы в противоречивости документов. Примером подобного рода нарушения может служить расхождение в составе совета директоров ак-

35 См.: Постановление ФАС Северо-Кавказского округа от 24 июня 2008 г. № Ф08-3509/2008 по делу № А32-22105/200763/601-107АП.

36 См.: Постановление ФАС Волго-Вятского округа от 13 апреля 2009 г. по делу № А79-5822/2008 Постановление ФАС Западно-Сибирского округа от 16 июля 2009 г. № Ф044080/2009(10312-А45-16) по делу № А45-16141/2008.

37 См.: Постановление ФАС Дальневосточного округа от 25 августа 2009 г. № Ф03-4247/2009 Постановление ФАС ВолгоВятского округа от 23 марта 2009 г. № А43-28310/2008-9-273.

38 См.: Постановление ФАС Дальневосточного округа от 25 августа 2009 г. № Ф03-4247/2009 по делу № A73-3854/2009, Постановление ФАС Волго-Вятского округа от 24 июня 2009 г. по делу № А11-271/2009-К2-22/32.

39 См.: Постановление ФАС Уральского округа от 1 сентября 2009 г. № Ф09-6402/09-С1 по делу № А60-11968/2009-С9, Определение ВАС РФ от 5 июня 2009 г. № ВАС-4343/09 по делу № А60-29487/2008-С9 Постановление ФАС Уральского округа от 5 февраля 2009 г. № Ф09-204/09-С1 по делу № A50-12066/08. 
ционерного общества, указанного в тексте ежеквартального отчета, и в списке аффилированных лиц, а так же долей принадлежащих им акций общества.

8. Сознательное искажение информации. Сознательное искажение информации осуществляется в первую очередь для введения кредиторов и инвесторов общества в заблуждение. Такие действия подпадают не только под административную, но и уголовную ответственность.

Следует отметить, что из общего количества административных дел на статьи за нарушение требований законодательства, касающихся предоставления и раскрытия информации на рынке ценных бумаг приходится 64,7 \% ${ }^{40}$.

С учетом практики раскрытия информации и анализа, наиболее часто совершаемых административных правонарушений при раскрытии информации, на наш взгляд, было бы целесообразно предусмотреть в Концепции следующий комплекс мер.

1. В настоящее время инвесторы и кредиторы при анализе инвестиционной привлекательности и анализе кредитоспособности акционерного общества помимо официально публикуемой информации обществом, обращают внимание на инвестиционные меморандумы. Учитывая это, было бы целесообразно, по аналогии с европейским правом, закрепить в Федеральном законе «Об акционерных обществах» требование о раскрытии широкой публике информации, содержащейся в инвестиционном меморандуме, и обязательной регистрации меморандумов. С этой целью, на наш взгляд, целесообразно п.1 ст. 92 ФЗ «Об акционерных обществах» дополнить словами «инвестиционный меморандум».

2. Одним из эффективных способов повышения качества раскрытия информации может стать наделение фондовых бирж полномочиями осуществлять контроль над раскрываемой информацией в установленный срок.

3. В соответствии с Положении о раскрытии информации эмитентами эмиссионных ценных бумаг при опубликовании информации в сети Интернет акционерное общество обязано обе-

40 Отчет о результатах контрольного мероприятия «Проверка эффективности в 2008 г. действующего законодательства и нормативной правовой базы о финансовом рынке и рынке ценных бумаг в целях стабилизации финансовой системы в Федеральной службе по финансовым рынкам, в Министерстве финансов Российской Федерации (по запросу)» // Бюллетень Счетной палаты. - 2010. - № 1 (145). - С. 97. спечить свободный и необременительный доступ к информации, публикуемой на сайте. По нашему мнению, было бы целесообразным создать подконтрольный ФСФР, единый Интернет портал для раскрытия информации. В таком случае было бы проще проверять, опубликована ли информация конкретного акционерного общества в Интернете. Также акционеры и инвесторы без труда смогут получить всю интересующую их информация на одном сайте, не тратя время на поиск.

4. Выполнение требований по раскрытию информации, содержащейся во внутренних корпоративных документах, стало бы более эффективным, если бы профессиональная организация имела полномочия определять, должна ли раскрываться та или иная информация и следила за качеством раскрываемой информации. Подобного рода функции могли бы взять на себя саморегулируемые организации. В уставах акционерных обществ может быть предусмотрено, что в случае возникновения спора между акционером, желающим получить определенную информацию, и акционерным обществом, отказывающим акционеру, спор передается на рассмотрение соответствующей организации, которая и определяет необходимость предоставления акционеру запрашиваемой им информации.

Таким образом, подводя итог проведенного исследования механизма административно-правового регулирования деятельности акционерных обществ можно сделать следующие выводы:

1. Механизм административно-правового регулирования деятельности акционерных обществ представляет собой упорядоченную совокупность взаимосвязанных и взаимодействующих административно-правовых средств, при помощи которых обеспечивается результативное правовое воздействие на общественные отношения, представляющие повторяющуюся совокупность последовательно осуществляемых операций, или стадий, в соответствии с целями, задачами и функциями регулирования деятельности акционерных обществ.

2. Составляющими элементами механизма административно-правового регулирования деятельности акционерных обществ являются:

- $\quad$ нормы права;

- государственные органы, осуществляющие контроль над акционерными обществами;

- юридические процедуры. 


\section{Библиография}

1. Рапопорт И.Я. Общественный закон об АО // Вестник Советской Юстиции. - 1928. - № 5.

2. Рассказов 0.Л. Первые акционерные компании в России // История государства и права. - 2001. - № 3.

3. Рогачева 0.С. Административно-правовой статус адвоката в производстве по делам о нарушениях законодательств о налогах и сборах. - Воронеж, 2003.

4. Свердлов Г. Израэлит М.Н. Акционерные общества. Правовые основания деятельности акционерных обществ (с участием и без участия государственного капитала). - М., 1927.

5. Соколов И. Акционерные общества и экономическая реформа // Советская юстиция. - 1990. - № 2.

6. Силвер А.Б., Слейд Д.Р. Корпорации США и акционерные общества России // Закон. - 1992. - № 2.

7. Стиглиц Дж.Ю. Экономика государственного сектора / Пер. с англ. - М., 1997.

8. Суханов Е. Акционерные общества и другие юридические лица в новом гражданском законодательстве // Хозяйство и право. - 1997. - № 1.

9. Сыродоева О.Н. Акционерное право США и России. Сравнительный анализ. - М.,1996.

10. Сусликов В.Н Функции государственного управления и экономика // Административное право Российской Федерации. Проблемные вопросы развития отрасли правовой системы и преподавания курса. - Новгород, 1999.

11. Костенников М.В. К вопросу о некоторых актуальных проблемах административного права // NB: Административное право и практика администрирования. - 2013. - 4. - С. 71-95. DOI: 10.7256/23069945.2013.4.8840. URL: http://www.e-notabene.ru/al/article_8840.html

12. Куракин А.В. Административно-правовые аспекты юридической ответственности в механизме противодействия коррупции в системе государственной службы Российской Федерации // NB: Административное право и практика администрирования. - 2013. - 7. - C. 137-157. DOI: 10.7256/23069945.2013.7.9954. URL: http://www.e-notabene.ru/al/article_9954.html

\section{References}

1. Rapoport I.Ya. Obshchestvennyi zakon ob AO // Vestnik Sovetskoi Yustitsii. - 1928. - № 5.

2. Rasskazov O.L. Pervye aktsionernye kompanii v Rossii // Istoriya gosudarstva i prava. - 2001. - № 3.

3. Rogacheva O.S. Administrativno-pravovoi status advokata $\mathrm{v}$ proizvodstve po delam o narusheniyakh zakonodatel'stv o nalogakh i sborakh. - Voronezh, 2003.

4. Sverdlov G. Izraelit M.N. Aktsionernye obshchestva. Pravovye osnovaniya deyatel'nosti aktsionernykh obshchestv (s uchastiem i bez uchastiya gosudarstvennogo kapitala). - M., 1927.

5. Sokolov I. Aktsionernye obshchestva i ekonomicheskaya reforma // Sovetskaya yustitsiya. - 1990. - № 2.

6. Silver A.B., Sleid D.R. Korporatsii SShA i aktsionernye obshchestva Rossii // Zakon. - 1992. - № 2.

7. Stiglits Dzh.Yu. Ekonomika gosudarstvennogo sektora / Per. s angl. - M., 1997.

8. Sukhanov E. Aktsionernye obshchestva i drugie yuridicheskie litsa v novom grazhdanskom zakonodatel'stve // Khozyaistvo i pravo. - 1997. - № 1.

9. Syrodoeva O.N. Aktsionernoe pravo SShA i Rossii. Sravnitel'nyi analiz. - M.,1996.

10. Suslikov V.N Funktsii gosudarstvennogo upravleniya i ekonomika // Administrativnoe pravo Rossiiskoi Federatsii. Problemnye voprosy razvitiya otrasli pravovoi sistemy i prepodavaniya kursa. - Novgorod, 1999.

11. Kostennikov M.V. K voprosu o nekotorykh aktual'nykh problemakh administrativnogo prava // NB: Administrativnoe pravo i praktika administrirovaniya. - 2013. - 4. - C. 71-95. DOI: 10.7256/23069945.2013.4.8840. URL: http://www.e-notabene.ru/al/article_8840.html

12. Kurakin A.V. Administrativno-pravovye aspekty yuridicheskoi otvetstvennosti v mekhanizme protivodeistviya korruptsii v sisteme gosudarstvennoi sluzhby Rossiiskoi Federatsii // NB: Administrativnoe pravo i praktika administrirovaniya. - 2013. - 7. - C. 137-157. DOI: 10.7256/2306-9945.2013.7.9954. URL: http://www.enotabene.ru/al/article_9954.html 